\title{
Perbandingan Uji Budi Daya Lebah Jenis Heterotrigona itama pada Empat Tipe Vegetasi \\ (Comparision of Meliponiculture using Heterotrigona itama Placed at Four Different Vegetations)
}

\section{Avry Pribadi}

\author{
Balai Litbang Teknologi Serat Tanaman Hutan \\ Jl. Raya Bangkinang-Kuok-km. 9 Bangkinang 28401 Kotak Pos 4/BKN-Riau \\ Tlp.: (0761) 6700911; Fax.: (0761) 6700768
}

Email: avrypribadi@gmail.com

Tanggal diterima : 25 Februari 2021; Tanggal direvisi : 16 Agustus 2021; Tanggal disetujui : 22 September 2021

\begin{abstract}
Nowadays, meliponiculture becomes a popular activity for most beekeepers since it is not complicated as apiculture. Heterotrigona itama is common species of stingless bees that becomes one of the most favorites for most meliponiculturists in Indonesia. On the other hand, location and vegetation are essential factors that influence the success of practicing meliponiculture. This study aimed to evaluate the development of $\underline{\mathrm{H}}$. itama at four locations (heterogenic yard field, calyandra plantation, pine forest, and oil palm plantation). Three times observations were conducted in June, August, and October 2016 toward the volume of brood, the number of honey, and the number of pollen pots. A randomized completely design was assigned in this study. Data were analyzed by conducting ANOVA and repeated measures that comparing between locations and observation times. Results showed that at the end of observation, the volume of brood was significantly high in oil palm plantations and the volume of brood was low in Pine forest. Meanwhile, the number of honey pots was significantly high in the heterogenic yard field and significantly low in the Pine forest. Furthermore, pollen pots were significantly high in oil palm plantations and low in Pine forests. This study revealed that low land and heterogeny yard are more suitable for keeping H. itama.
\end{abstract}

Keyword: Meliponoculture, heterotrigona itama, honey pots, pollen pots, vegetations

\begin{abstract}
Abstrak
Beberapa tahun belakangan ini, budi daya lebah tanpa sengat menjadi sangat popular dibandingkan lebah bersengat, karena budi dayanya yang relatif sederhana dan tidak rumit. Mayoritas jenis yang banyak dibudidayakan oleh para peternak lebah adalah Heterotrigona itama. Kesuksesan budi daya lebah tidak bersengat bergantung pada lokasi dan kondisi vegetasi, sehingga pemilihan lokasi sebelum budi daya merupakan hal yang penting. Tujuan penelitian untuk mengetahui perkembangan $\mathrm{H}$. itama yang ditempatkan pada vegetasi yang berbeda, yaitu lahan pekarangan heterogen, kebun kaliandra, hutan pinus, dan kebun kelapa sawit. Pengumpulan data dilakukan sebanyak tiga kali, yaitu pada bulan Juni, Agustus, dan Oktober tahun 2016 terhadap volume sel anakan, jumlah kantung madu yang terbentuk, dan jumlah kantung tepung sari/polen. Penelitian menggunakan rancangan acak lengkap.
\end{abstract}


Data dianalisis secara ANOVA dan pengukuran berulang terhadap waktu pengamatan dan lokasi. Hasil menunjukkan bahwa volume sel anakan tertinggi pada akhir pengamatan pada bulan Oktober terdapat di lokasi kebun sawit dan terendah terdapat di hutan pinus. Perkembangan jumlah kantung madu pada koloni tertinggi terdapat di lahan pekarangan dan terendah terdapat di hutan pinus. Selanjutnya, perkembangan jumlah kantung polen pada koloni H. itama tertinggi terdapat di kebun sawit dan terendah di hutan pinus. Hasil ini menunjukkan bahwa lokasi yang tepat untuk pemeliharaan H. itama berada di lingkungan yang heterogen dan berada di dataran rendah.

\section{Kata kunci: Budi daya, tegakan, lebah tanpa sengat, Heterotrigona itama, kantung madu, kantung polen}

\section{Pendahuluan}

Indonesia memiliki paling sedikit tujuh spesies lebah bersengat, yaitu Apis florea, Apis adreniformis, Apis koschevnikovi, Apis dorsata dorsata, Apis dorsata binghami, Apis cerana, dan Apis nigorcincta (Engel, 2012; Hepburn \& Radloff, 2011). Selain lebah bersengat, Indonesia juga memiliki keragaman lebah tidak bersengat yang lebih tinggi. Engel et. al. (2019) mendapati bahwa terdapat 46 spesies lebah tidak bersengat yang berhasil diidentifikasi di Indonesia dan merupakan jumlah yang terbanyak di kawasan Asia, meskipun masih kalah jauh dari Brazil yang memiliki 244 spesies (De Menezes Pedro, 2014). Di Indonesia, serangga ini memiliki beberapa nama lokal, antara lain lanceng (bahasa jawa), galo-galo (bahasa minang), teuweul (bahasa sunda), keledan (bahasa lombok), kelulut (bahasa melayu) dan ketape (bahasa sulawesi) (Riendriasari \& Krisnawati, 2017). Saat ini jenis yang banyak dibudidayakan salah satunya adalah jenis Heterotrigona itama.

Seperti halnya serangga pada umumnya, morfologi H. itama terdiri atas kepala, dada, dan perut. Selain itu juga terdapat bagian antena, mata, sayap, dan kaki (Engel et al., 2019; Fadhilah \& Rizkika, 2015; QuezadaEuán, 2018; Mayes et al., 2019; Abdul et al., 2017). Sebagai serangga sosial, koloni lebah H. itama hidup berkoloni dan berhabitat di bambu, tanah, dan batang kayu (Michener, 2013; Erwan \& Yanuartati, 2012). Jenis ini memiliki ukuran 4,00-4,88 $\mathrm{mm}$ dan memiliki warna tubuh yang lebih gelap (Trianto \& Purwanto, 2020). H. itama merupakan jenis lebah kelulut yang paling banyak ditemukan di hutan Sumatera, memiliki sifat agresif, menyukai nektar dengan kosentrasi tinggi, dan menyukai nektar bunga dari kelompok Spermathophyta (Basari et. al., 2018; Fahimee et al., 2021). Meskipun bersifat cenderung lebih agresif, namun karena kemudahan dalam mengelola jenis ini, ketersediaan di alam yang masih banyak, dan produksi madunya yang lebih tinggi dibanding jenis lain menjadikan jenis lebah kelulut banyak dipilih oleh para peternak lebah tidak bersengat. Bahkan jenis lebah ini dipilih oleh Taman Nasional Bukit Tiga Puluh sebagai kegiatan utama pemberdayaan masyarakat Talang Mamak di kawasannya (Pribadi et. al., 2020).

Berbeda dengan Apis mellifera yang rentan terhadap serangan hama Varroa destructor (Kuntadi, 2016; Kuntadi \& Andadari, 2013; Harjanto et. al., 2020; Ramsey et al., 2019) lebah kelulut cenderung lebih tahan terhadap serangan hama. Selain itu, lebah kelulut memiliki kemudahan dalam pemeliharaan dan madu yang dihasilkan memiliki kualitas yang lebih baik dibandingkan madu dari lebah bersengat (Pribadi \& Wiratmoko, 2019; Wiratmoko \& Pribadi, 2020; Wong et. al., (2019). Propolis yang dihasilkan baik oleh $\mathrm{H}$. itama dan A. mellifera sama-sama memiliki aktivitas antibakteri terutama dalam menurunkan aktivitas Escherichia coli dan Staphylococcus aureus serta khusus pada madu yang dihasilkan oleh lebah tidak bersengat beberapa studi mengatakan bahwa tidak mengandung 
Clostridium karena memiliki pH 2,40-3,40 (Lani et. al., 2017; $\mathrm{Ng}$ et. al., 2020; Nweze et. al., 2017; Bankova et al., 2019; Toreti et. al., 2013; Shamsudin et. al., 2019). Khusus untuk propolis, pemanenannya dapat menggunakan metode kawat kasa ataupun plastik mika yang relatif aman dan tidak bersifat destruktif (Pribadi, 2020). Sedangkan bee bread $\mathrm{H}$. itama yang sampai sekarang belum banyak dimanfaatkan ternyata memiliki kandungan protein yang tinggi (21,70-23,33\%) (Mohammad et. al., 2020; Mohd \& Zin, 2020).

Antusias yang tinggi terhadap budi daya lebah kelulut sering berujung pada kegagalan karena minimnya informasi mengenai kesesuaian habitat (Syafrizal et. al., 2012; Michener, 2007; Kek et. al., 2017). Jika pada lebah sialang (Apis dorsata) hutan memegang peranan yang cukup penting dalam perkembangan koloni dan produktivitas madu (Pribadi, 2020), maka diduga terdapat faktor yang sama juga yang berpengaruh terhadap perkembangan lebah kelulut oleh karena itu, diperlukan studi kesesuaian dan pemilihan lokasi $\mathrm{H}$. itama untuk menghindari kegagalan dalam budi daya lebah kelulut. Oleh sebab itu, tujuan penelitian adalah mengetahui perkembangan koloni $\mathrm{H}$. itama pada empat lokasi yang memiliki perbedaan struktur vegetasi, sehingga dapat dijadikan dasar untuk kegiatan pengembangan selanjutnya.

\section{Metodologi}

\subsection{Lokasi dan Waktu Penelitian}

Penelitian dilakukan di lokasi yang mewakili dataran tinggi dan rendah. Pada dataran tinggi, penelitian dilakukan di lahan perkebunan di Kecamatan Salimpaung Kabupaten Tanah Datar, Sumatera Barat (998 m dpl) dan hutan pinus di Kecamatan Tanjung Pauh Kabupaten Tanah Datar, Sumatera Barat (519 mdpl). Pada dataran rendah, penelitian dilakukan di Dusun Pulau Belimbing di Kabupaten Kampar Riau, (44 mdpl) yang mewakili pekarangan dan Kelurahan Selensen, Kabupaten Indragiri Hilir, Riau (40 mdpl) yang mewakili kebun sawit. Penelitian dilakukan pada bulan April 2016 sampai Desember 2016. Seluruh koloni H. itama yang digunakan pada penelitian ini berasal dari Desa Kuok, Kecamatan Kuok, Kabupaten Kampar, Provinsi Riau. Setelah dilakukan aklimatisasi di Desa Kuok, seluruh koloni diletakkan pada berbagai lokasi penelitian yang telah ditentukan.

\subsection{Metode}

Bahan yang digunakan adalah koloni H. itama, papan kayu, paku, plastik mika, tripleks, dan kotak stup. Koloni H. itama berasal dari Kabupaten Kampar, Riau dan telah dipindahkan ke kotak stup berukuran $20 \mathrm{~cm} \times 20 \mathrm{~cm} \times 15 \mathrm{~cm}$ dengan dipasang kotak eram madu (topping) berukuran 40 $\mathrm{cm}$ x $40 \mathrm{~cm}$ x $10 \mathrm{~cm}$. Untuk penyeragaman dan aklimatisasi, maka koloni dipindahkan ke kotak stup (kotak eram madu-topping) lalu didiamkan dan diaklimatisasi di lokasi asalnya di Desa Kuok, Kecamatan Kuok, Kabupaten Kampar, Provinsi Riau selama satu bulan. Asal koloni H. itama berada pada ketinggian $44 \mathrm{~m}$ dpl, tipe iklim A menurut Schmidt-Ferguson periode 10 tahun (2009 - 2018) dengan curah hujan rata-rata $283 \mathrm{~mm}$ per tahun antara, dan temperatur udara antara $27-33^{\circ} \mathrm{C}$.

Rancangan penelitian yang digunakan adalah rancangan acak lengkap dengan perlakuan lokasi penempatan koloni $\mathrm{H}$. itama. Setiap lokasi ditempatkan tujuh koloni H. itama sebagai ulangan. Data yang diambil dari penelitian ini adalah volume sel anakan lebah dan jumlah kantung madu serta polen. Volume sel anakan lebah diperoleh dengan mengukur panjang kali lebar kali tinggi susunan telur. Pengukuran dilakukan dengan membuka kotak eram madu agar memudahkan dalam proses pengukuran telur. Jumlah kantung madu dan polen diperoleh dengan cara menghitung kantung madu dan polen yang berada di kotak eram madu pada setiap pengamatannya.

Untuk mengetahui kondisi karakteristik vegetasi setiap lokasi penelitian, maka dilakukan analisis vegetasi 
menurut metode Indriyanto (2006). Untuk mengamati kondisi vegetasi tumbuhan bawah dilakukan pengamatan berukuran 1 m x $1 \mathrm{~m}$ sebanyak 2 petak yang diletakkan berdampingan. Untuk kelas pancang menggunakan ukuran petak $5 \mathrm{~m}$ x $5 \mathrm{~m}$ sebanyak 1 petak, kelas tiang menggunakan $10 \mathrm{~m}$ x 10 m sebanyak 1 petak, dan petak ukuran $20 \mathrm{~m}$ x $20 \mathrm{~m}$ sebanyak 1 petak untuk kelas pohon. Penentuan petak pengamatan dilakukan secara systematic sampling dengan banyaknya petak pengamatan adalah sepuluh petak setiap lokasinya. Indeks Nilai Penting (INP) digunakan untuk mengetahui struktur vegetasi pada keempat lokasi penelitian. Untuk menentukan INP, terdapat dua parameter yang digunakan yaitu kerapatan relatif (KR) dan frekuensi relatif (FR). Rumus yang digunakan adalah:

$$
\begin{aligned}
& \text { Kerapatan } \quad=\text { Jumlah individu : luas } \\
& \text { Jenis }(\mathrm{K}) \quad \text { petak pengamatan } \\
& \text { Kerapatan } \quad=\text { (K: Jumlah } \mathrm{K} \text { seluruh } \\
& \text { Relatif (KR) jenis) x } 100 \% \\
& \text { Frekuensi }(\mathrm{F})=\text { (Jumlah petak } \\
& \text { ditemukan spesies : } \\
& \text { Jumlah petak contoh) } \\
& \text { x } 100 \% \\
& \text { Frekensi } \quad=(\mathrm{F}: \text { Jumlah } \mathrm{F} \text { seluruh } \\
& \text { Relatif (FR) jenis) x 100\% } \\
& \text { Indeks Nilai }=\mathrm{KR}+\mathrm{FR} \\
& \text { Penting }
\end{aligned}
$$

\subsection{Analisis Data}

Analisis ragam (ANOVA) digunakan untuk menentukan apakah lokasi berpengaruh signifikan terhadap volume sel anakan lebah, jumlah kantung madu, dan polen. Uji lanjut digunakan mengetahui perlakuan mana yang berbeda nyata. Selain itu, dilakukan uji pengamatan berulang untuk mengetahui ada tidaknya perubahan terhadap volume sel anakan lebah dan jumlah kantung madu serta polen selama tiga kali pengamatan. Hal ini dilakukan untuk mengetahui ada tidaknya perkembangan yang nyata antara waktu pengamatan. Data berupa struktur vegetasi digunakan untuk menentukan tumbuhan dominan pada empat lokasi yang diamati, 96 sehingga dapat dijadikan acuan dalam menentukan dugaan jenis tanaman pakan yang kemungkinan didatangi oleh lebah kelulut.

\section{Hasil dan Pembahasan}

\subsection{Hasil}

Hasil penelitian analisis ragam menunjukkan bahwa lokasi penempatan koloni $\mathrm{H}$. itama berpengaruh signifikan terhadap volume sel anakan lebah, jumlah kantung madu dan polen. Pada pengamatan di bulan Juni 2016, rata-rata volume sel anakan lebah yang tertinggi terdapat pada lokasi hutan pinus $\left(969,29 \mathrm{~cm}^{3}\right)$ (Tabel 1). Akan tetapi, nilai ini tidak berbeda nyata pada kebun kaliandra dan kebun kelapa sawit. Selanjutnya, nilai terendah terdapat pada lokasi lahan pekarangan $\left(873,29 \mathrm{~cm}^{3}\right)$. Hasil berbeda terlihat pada pengamatan selanjutnya di bulan Agustus dan Oktober 2016 yang menunjukkan penempatan stup di lahan pekarangan memiliki volume sel anakan lebah tertinggi $\left(1.346,43 \mathrm{~cm}^{3}\right)$. Akan tetapi, nilai ini tidak berbeda nyata dengan volume sel anakan lebah pada kebun kaliandra dan kelapa sawit. Nilai terendah terdapat pada lahan pinus $(967,14$ $\mathrm{cm}^{3}$ ). Pada akhir pengamatan di bulan Oktober 2016, nilai tertinggi terdapat pada kebun kelapa sawit $\left(2.146 \mathrm{~cm}^{3}\right)$ yang berbeda nyata dengan tiga lokasi lainnya ( $\mathrm{p}$ $<0,05$ ). Rata-rata volume sel anakan lebah terendah terdapat pada hutan pinus (976.43 $\mathrm{cm}^{3}$ ).

Hasil analisis repeated measures terhadap volume sel anakan lebah menunjukkan bahwa adanya perbedaan yang nyata antara waktu pengamatan di lokasi pekarangan ( $\mathrm{p}<0,05)$, kebun kelapa sawit ( $\mathrm{p}<0,05)$, dan kebun kaliandra pada pengamatan bulan Juni dan Agustus ( $p<0,05$ ). Sementara itu lokasi hutan pinus tidak menunjukkan adanya perbedaan yang nyata antara pengamatan $(p>0,05)$. Hal ini menunjukkan terdapat perkembangan sel anakan lebah pada lokasi kebun sawit dan lahan pekarangan lebih baik dibandingkan dua lokasi lain (hutan pinus yang tidak 
menunjukkan adanya perbedaan volume sel anakan lebah antara waktu pengamatan).

Pada pengamatan parameter kantung madu H. itama menunjukkan bahwa lokasi berpengaruh nyata. Rata-rata tertinggi terdapat pada pengamatan bulan Juni 2016 di kebun kaliandra (13 kantung) (Tabel 3). Akan tetapi, nilai ini tidak berbeda nyata dengan lahan pekarangan $(11 \pm 0,43$ kantung) ( $\mathrm{p}<0,05)$ dan berbeda nyata dengan penempatan stup di hutan pinus dan kebun kelapa sawit yang masing-masing memiliki nilai 4,43 $\pm 0,48$ kantung dan 2,14 $\pm 0,63$ kantung. Fenomena yang berbeda terjadi pada pengamatan bulan Agustus dan Oktober 2016. Pada bulan Agustus 2016, di lahan pekarangan memiliki jumlah kantung madu terbanyak $(19,29 \pm 0,68$ kantung $)$ (Tabel 3). Selain itu, nilai ini berbeda nyata dengan ketiga lokasi lainnya dan masing- masing lokasi memiliki nilai yang berbeda nyata antara satu dengan lainnya $(\mathrm{p}<0,05)$. Jumlah kantung madu terendah terdapat pada stup yang ditempatkan di kebun sawit $2,29 \pm 0,55$ kantung. Pada pengamatan di bulan Oktober 2016 menunjukkan hasil yang hampir serupa dengan pengamatan di bulan Agustus 2016. Sementara pada pengamatan ketiga, menunjukkan hasil yang hampir serupa dengan pengamatan kedua. Nilai tertinggi terdapat pada stup yang ditempatkan di lahan pekarangan (31 $\pm 0,69$ kantung) dan nilai ini berbeda nyata dengan tiga lokasi lainnya $(\mathrm{p}<0,05)$. Nilai terendah terdapat pada stup yang ditempatkan pada lokasi hutan pinus dan kebun kelapa sawit yang masing-masing memiliki nilai $6,57 \pm 0,61$ kantung dan 3,14 $\pm 0,83$ kantung (Tabel 2).

Tabel (Table) 1. Rata-rata perkembangan volume sel anakan lebah H. itama pada empat lokasi $\left(\mathrm{cm}^{3}\right)$ (Average of $\underline{\mathrm{H}}$. itama`s brood volume at four locations)

\begin{tabular}{|c|c|c|c|}
\hline \multirow{2}{*}{ Lokasi (Locations) } & \multicolumn{3}{|c|}{$\begin{array}{l}\text { Rata-rata perkembangan kantung madu }(\mathrm{x} \pm \mathrm{sd}) \mathrm{cm}^{3} \\
\text { (Average of honey pots } \pm \mathrm{sd})\left(\mathrm{cm}^{3}\right)\end{array}$} \\
\hline & Juni (June) & Agustus (August) & Oktober (October) \\
\hline pekarangan & $873,29 \pm 5,11 \mathrm{a} / \mathrm{a}$ & $1346,43 \pm 20,72 \mathrm{~b} / \mathrm{b}$ & $1674,29 \pm 49,40 \mathrm{c} / \mathrm{c}$ \\
\hline $\begin{array}{l}\text { Kebun kaliandra } \\
\text { (Calyandra }\end{array}$ & $955,71 \pm 11,77 \mathrm{~b} / \mathrm{a}$ & $1116,43 \pm 94,96 \mathrm{ab} / \mathrm{b}$ & $1125 \pm 145,06 \mathrm{~b} / \mathrm{b}$ \\
\hline Hutan pinus (Pine & $969,29 \pm 14,45 \mathrm{~b} / \mathrm{a}$ & $967,14 \pm 18,70 \mathrm{a} / \mathrm{a}$ & $976,43 \pm 24,17 \mathrm{a} / \mathrm{a}$ \\
\hline $\begin{array}{l}\text { Kelapa sawit (Oil palm } \\
\text { plantation) }\end{array}$ & $950,71 \pm 26,51 \mathrm{~b} / \mathrm{a}$ & $1327,43 \pm 109,88 \mathrm{~b} / \mathrm{b}$ & $2146 \pm 84,36 \mathrm{~d} / \mathrm{c}$ \\
\hline eterangan (Remarks): $\begin{array}{r}\text { Hur } \\
\text { kolc }\end{array}$ & $\begin{array}{l}\text { kecil berbeda di bel } \\
\text { sedangkan perbedaar } \\
\text { lan nyata antara setia } \\
\text { the numbers indica }\end{array}$ & $\begin{array}{l}\text { g angka menunjukkan } p \\
\text { hadap huruf besar setelal } \\
\text { aris pada level } \alpha=0,05\end{array}$ & $\begin{array}{l}\text { daan nyata pada setiap } \\
\text { is miring menunjukkan } \\
\text { erent lower case letters } \\
n \text { columns, meanwhile } \\
\text { at the level of } \alpha=0.05 \text { ) }\end{array}$ \\
\hline
\end{tabular}


Tabel (Table) 2. Rata-rata perkembangan jumlah kantung madu H. itama pada empat lokasi (․․ itama's honey pot averages at four locations)

\begin{tabular}{|c|c|c|c|}
\hline \multirow[t]{2}{*}{ Lokasi (Locations) } & \multicolumn{3}{|c|}{$\begin{array}{l}\text { Rata-rata perkembangan kantung madu }(\mathrm{x} \pm \mathrm{sd}) \\
\text { (Kantong) } \\
\text { (Average of honey pots } \pm \mathrm{sd})(\text { Pots })\end{array}$} \\
\hline & Juni (June) & $\begin{array}{l}\text { Agustus } \\
(\text { August })\end{array}$ & $\begin{array}{l}\text { Oktober } \\
\text { (October) }\end{array}$ \\
\hline Lahan pekarangan (Yard field) & $11,00 \pm 0,43 \mathrm{~b} / \mathrm{a}$ & $19,29 \pm 0,68 \mathrm{~d} / \mathrm{c}$ & $31,00 \pm 0,69 \mathrm{c} / \mathrm{c}$ \\
\hline $\begin{array}{l}\text { Kebun kaliandra (Calyandra } \\
\text { plantation) }\end{array}$ & $13,00 \pm 0,95 \mathrm{~b} / \mathrm{a}$ & $11,14 \pm 0,705 \mathrm{c} / \mathrm{b}$ & $11,86 \pm 1,91 \mathrm{~b} / \mathrm{b}$ \\
\hline Hutan pinus (Pine forest) & $4,43 \pm 0,48 \mathrm{a} / \mathrm{a}$ & $6,14 \pm 0,55 \mathrm{~b} / \mathrm{b}$ & $6,57 \pm 0,61 \mathrm{a} / \mathrm{b}$ \\
\hline $\begin{array}{l}\text { Kelapa sawit } \quad \text { (Oil } \\
\text { plantation) }\end{array}$ & $2,14 \pm 0,63 \mathrm{a} / \mathrm{a}$ & $2,29 \pm 0,55 \mathrm{a} / \mathrm{a}$ & $3,14 \pm 0,83 \mathrm{a} / \mathrm{a}$ \\
\hline
\end{tabular}

Keterangan (Remarks): Huruf kecil berbeda di belakang angka menunjukkan perbedaan nyata pada setiap kolom, sedangkan perbedaan terhadap huruf besar setelah garis miring menunjukkan perbedaan nyata antara setiap baris pada level $\alpha=0,05$ (Different lower case letters behind the numbers indicate significant differences within columns, meanwhile uppercase letters after slash describe differences within row at the level of $\alpha=0.05$ )

Hasil analisis repeated measures terhadap perkembangan jumlah kantung madu menunjukkan adanya kecenderungan yang serupa dengan perkembangan volume sel anakan lebah. Hal ini terlihat dari adanya perbedaan yang nyata antara waktu pengamatan di lokasi lahan pekarangan $(\mathrm{p}<0,05)$ dan kebun kaliandra $(\mathrm{p}<0,05)$. Namun, di kebun kaliandra terjadi penurunan jumlah kantung madu jika dibandingkan di lokasi lahan pekarangan yang mengalami peningkatan jumlah kantung madu setiap pengamatannya (Tabel 2). Pada hutan pinus, perbedaan hanya terjadi pada pada pengamatan bulan Juni dan Agustus ( $p<0,05$ ). Di lokasi kebun sawit, tidak terdapat perbedaan yang nyata antara waktu pengamatan atau dengan kata lain, tidak ada penambahan jumlah kantung madu yang signifikan di setiap waktu pengamatan.
Rata-rata jumlah kantung polen, nilai tertinggi terdapat pada bulan Juni 2016 di lokasi kebun sawit ( $8 \pm 0,9$ kantung) (Tabel 5). Akan tetapi, nilai ini tidak beda nyata dengan lokasi di lahan pekarangan $(6,14 \pm$ 0,46 kantung) dan berbeda nyata dengan dua lokasi lainnya di kebun kaliandra (5 $\pm 0,31$ kantung) dan hutan pinus. $(1,86 \pm$ 0,34 kantung) $(\mathrm{p}<0,05)$. Pada pengamatan bulan Agustus 2016 secara umum menunjukkan bahwa stup yang ditempatkan di lokasi kebun sawit menunjukkan nilai tertinggi dan berbeda nyata dengan seluruh lokasi $(\mathrm{p}<0,05)$ dengan nilai terendah terdapat pada hutan pinus (2,57 $\pm 0,20$ kantung). Pada pengamatan bulan Oktober 2016, menunjukkan bahwa kecenderungan yang sama dengan pengamatan kedua di bulan Agustus 2016. Jumlah kantung polen memiliki nilai tertinggi di lokasi kebun kelapa sawit (16,71kantung) dan terendah pada hutan pinus $(2,86$ kantung) $(\mathrm{p}<0,05)$. 
Tabel (Table) 3. Rata-rata perkembangan jumlah kantung polen H. itama pada empat lokasi (․ㅡ. itama's pollen pots average at four locations)

\begin{tabular}{|c|c|c|c|}
\hline \multirow[t]{2}{*}{ Lokasi (Location) } & \multicolumn{3}{|c|}{$\begin{array}{l}\text { Rata-rata perkembangan kantung polen }(\mathrm{x} \pm \mathrm{sd}) \\
\text { (Kantong) } \\
\text { (Average of polen pots } \pm \mathrm{sd})(\text { Pots })\end{array}$} \\
\hline & Juni (June) & $\begin{array}{l}\text { Agustus } \\
\text { (August) }\end{array}$ & $\begin{array}{l}\text { Oktober } \\
\text { (October) }\end{array}$ \\
\hline Lahan pekarangan (Yard field) & $6,14 \pm 0,46 \mathrm{~b} c / \mathrm{a}$ & $11,00 \pm 0,53 \mathrm{c} / \mathrm{b}$ & $13,00 \pm 0,72 \mathrm{c} / \mathrm{c}$ \\
\hline $\begin{array}{l}\text { Kebun kaliandra (Calyandra } \\
\text { plantation) }\end{array}$ & $5,00 \pm 0,31 \mathrm{~b} / \mathrm{a}$ & $6,25 \pm 0,62 \mathrm{~b} / \mathrm{b}$ & $6,29 \pm 0,89 \mathrm{~b} / \mathrm{b}$ \\
\hline Hutan pinus (Pine forest) & $1,86 \pm 0,34 \mathrm{a} / \mathrm{a}$ & $2,57 \pm 0,20 \mathrm{a} / \mathrm{a}$ & $2,86 \pm 0,14 \mathrm{a} / \mathrm{a}$ \\
\hline $\begin{array}{l}\text { Kebun sawit (Oil palm } \\
\text { plantation) }\end{array}$ & $8,00 \pm 0,90 \mathrm{c} / \mathrm{a}$ & $13,86 \pm 0,77 \mathrm{~d} / \mathrm{a}$ & $16,71 \pm 0,84 \mathrm{~d} / \mathrm{c}$ \\
\hline $\begin{array}{l}\text { Huruf ke } \\
\text { kolom, se } \\
\text { perbedaa } \\
\text { behind } t \\
\text { uppercas }\end{array}$ & $\begin{array}{l}\text { di belakang a } \\
\text { erbedaan terhac } \\
\text { ara setiap baris } \\
\text { indicate sig }\end{array}$ & $\begin{array}{l}\text { enunjukkan per } \\
\text { If besar setelah } \\
\text { vel } \alpha=0,05(D \\
\text { differences wit }\end{array}$ & $\begin{array}{l}\text { nyata pada setiap } \\
\text { ring menunjukkan } \\
\text { lower case letters } \\
\text { lumns, meanwhile } \\
\text { level of } \alpha=0.05 \text { ) }\end{array}$ \\
\hline
\end{tabular}

Hasil analisis repeated measures terhadap perkembangan jumlah kantong polen menunjukkan bahwa waktu pengamatan berpengaruh nyata yang hanya terjadi di lokasi kebun sawit $(\mathrm{p}<0,05)$. Untuk tiga lokasi lain (kebun kaliandra, lahan pekarangan dan hutan pinus) menunjukkan bahwa waktu pengamatan tidak berpengaruh nyata terhadap jumlah kantong polen. Di lokasi lahan pekarangan dan kebun kaliandra hanya menunjukkan perbedaan yang tidak nyata antara pengamatan bulan Agustus dengan Oktober ( $\mathrm{p}>0,05$ ). Hal ini menunjukkan bahwa pada lokasi kebun sawit terjadi penambahan jumlah kantung polen, sedangkan ketiga lokasi lain tidak terjadi penambahan jumlah kantung polen.

Pada tingkat pohon, jenis vegetasi yang mendominasi pada hutan pinus, kebun kaliandra, dan pekarangan masingmasing adalah jenis Pinus merkusii (INP = 31,87), Calliandra calothyrus (INP = $31,53)$, dan Cocos nucifera $($ INP $=18,09)$
(Tabel 4). Pada tingkat tiang, jenis Cinnamomum sp. $(\mathrm{INP}=33,43), \mathrm{C}$. calothyrus $(\mathrm{INP}=18,75)$, dan Hevea brasilliensis $(\mathrm{INP}=9,52)$ merupakan jenis yang mendominasi dibanding jenis-jenis lainnya pada lokasi hutan pinus, kebun kaliandra, dan pekarangan. Pada tingkat pancang, jenis Macaranga sp. (INP = 17,67), C. calothyrus $(\mathrm{INP}=71,22)$, dan Stachytarpheta indica $(\mathrm{INP}=6,54)$ adalah yang mendominasi pada lokasi hutan pinus, kebun kaliandra, dan pekarangan. namun di kebun sawit tidak diperoleh data tentang tanaman pada tingkat pohon, tiang, dan pancang dikarenakan pada kebun sawit menerapkan manajemen zero weed, sehingga hanya jenis kelapa sawit saja yang dapat dihitung. Pada tingkat semai, jenis Dicranopteris linearis (INP $=27,31)$, Echinochloa sp. (INP = 10,30), Mimosa sp. (INP $=28,03)$, dan Paspalum conjugatum (INP $=19,50)$ mendominasi berturut-turut pada lokasi hutan pinus, kebun kaliandra, pekarangan, dan kebun kelapa sawit. 
Tabel (Table) 4. Indeks nilai penting pada jenis tanaman yang berada pada empat lokasi (Important value index of vegetations located at four different locations)

\begin{tabular}{|c|c|c|c|c|}
\hline \multirow[b]{2}{*}{$\begin{array}{c}\text { Nama spesies (Spesies } \\
\text { names) }\end{array}$} & \multicolumn{4}{|c|}{ Indeks nilai penting (Important value index) } \\
\hline & $\begin{array}{l}\text { Hutan pinus } \\
\text { (Pine forest) }\end{array}$ & $\begin{array}{c}\text { Kebun kaliandra } \\
\text { (Calyandra } \\
\text { plantation) }\end{array}$ & $\begin{array}{l}\text { Hutan pinus } \\
\text { (Pine forest) }\end{array}$ & $\begin{array}{l}\text { Kebun sawit } \\
\text { (Oil palm } \\
\text { plantation) }\end{array}$ \\
\hline \multicolumn{5}{|l|}{$\begin{array}{l}\text { a. Tingkat semai } \\
\text { (Seedling) }\end{array}$} \\
\hline Ottochloa spinosa & 2,86 & 9,32 & 13,90 & - \\
\hline Imperrata cylindrical & 17,32 & 16,76 & - & 3,50 \\
\hline Dicranopteris linearis & 27,31 & - & - & - \\
\hline Clidemia hirta & 18,32 & - & 5,43 & 7,70 \\
\hline Curcumae domesticae & 24,77 & - & 4,50 & - \\
\hline Mikania micrantha & - & 6,30 & 16,94 & - \\
\hline Caladium sp. & - & 7,30 & - & - \\
\hline Mimosa sp. & - & 8,99 & 28,03 & - \\
\hline Eupathorium sp. & - & 7,64 & 7,24 & - \\
\hline Ageratum conyzoides & - & 7,30 & 7,51 & 4,50 \\
\hline Echinochloa sp. & - & 10,30 & 5,09 & - \\
\hline Assystasia $\mathrm{sp}$. & - & - & 23,60 & 15,50 \\
\hline Melastoma malabatrichum & - & - & 15,77 & 1,87 \\
\hline Antigonon leptosus & - & - & 6,59 & - \\
\hline Paspalum conjugatum & - & - & - & 19,50 \\
\hline \multicolumn{5}{|l|}{$\begin{array}{l}\text { b. Tingkat pancang } \\
\text { (Sapling) }\end{array}$} \\
\hline Cinnamomum sp. & 13,13 & - & - & \\
\hline Macaranga sp. & 17,67 & - & - & \\
\hline Calliandra calothyrus & - & 71,22 & - & \\
\hline Piper sp. & - & 34,09 & - & \\
\hline Moutsia sp. & - & 40,42 & - & \\
\hline Stachytarpheta indica & - & - & 6,54 & \\
\hline Hevea brasiliensis & - & - & 3,28 & \\
\hline Aquilaria sp. & - & - & 3,10 & \\
\hline Macaranga sp. & - & - & 5,48 & \\
\hline \multicolumn{5}{|l|}{ c. Tingkat tiang (Pole) } \\
\hline Cinnamomum sp. & 33,43 & - & - & \\
\hline Ficus sp. & 14,62 & - & - & \\
\hline Calliandra calothyrus & - & 18,75 & - & \\
\hline Villebrunea sp. & - & 11,89 & - & \\
\hline Cyathea sp. & - & 12,36 & - & \\
\hline Macaranga sp. & - & - & 5,87 & \\
\hline Eugenia aquea & - & - & 5,33 & \\
\hline Hevea brasiliensis & - & - & 9,52 & \\
\hline Litsea sp. & - & - & 4,36 & \\
\hline Shorea sp. & - & - & 2,18 & \\
\hline Aquilaria sp. & - & - & 5,22 & \\
\hline
\end{tabular}


Lanjutan (Continue)

\begin{tabular}{lcccc}
\hline \multirow{2}{*}{$\begin{array}{c}\text { Nama spesies (Spesies } \\
\text { names) }\end{array}$} & \multicolumn{3}{c}{ Indeks nilai penting (Important value index) } \\
\cline { 2 - 5 } & $\begin{array}{c}\text { Hutan pinus } \\
\text { (Pine forest) }\end{array}$ & $\begin{array}{c}\text { Kebun kaliandra } \\
\text { (Calyandra } \\
\text { plantation) }\end{array}$ & $\begin{array}{c}\text { Hutan pinus } \\
\text { (Pine forest) }\end{array}$ & $\begin{array}{c}\text { Kebun sawit } \\
\text { (Oil palm } \\
\text { plantation) }\end{array}$ \\
\hline d. Tingkat pohon (Tree) & 11,79 & - & 12,36 & - \\
Citrus sp. & 31,87 & - & 17,59 \\
Pinus merkusii & 8,78 & 16,44 & - \\
Hevea brasilliensis & 5,89 & - & - \\
Arthocarpus sp. & 13,98 & - & - \\
Pometia pinnata & 5,92 & - & - \\
Tectona grandis & 5,88 & - & - \\
Archidendron pauciflorum & - & 31,53 & 15,34 \\
Calliandra calothyrus & - & 15,48 & 12,57 \\
Musa sp. & - & 13,44 & - \\
Theobroma cacao & - & 13,40 & 8,65 \\
Persea gratissima & - & 7,15 & 8,27 \\
Carica papaya & - & - & 9,30 \\
Artocarpus heterophylus & - & - & 11,55 \\
Durio zibethinus & - & - & 18,09 \\
Nephelium sp. & - & - & 13,88 \\
Cocos nucifera & - & - & 7,77 \\
Archidendron pauciflorum & - & - & 10,27 \\
Mangifera indica & & - & \\
Artocarpus integer & & & \\
\hline
\end{tabular}

\subsection{Pembahasan}

Tingginya rata-rata volume sel anakan lebah pada kebun kelapa sawit dan pekarangan di bulan Oktober dibandingkan bulan Juni menunjukkan populasi H. itama pada dua lokasi tersebut menunjukkan adanya perkembangan yang lebih baik dibandingkan penempatan di lokasi kebun kaliandra dan hutan pinus. Diduga ada dua faktor yang mempengaruhi hasil ini. Pertama adalah kurangnya ketersediaan tanaman sumber pakan terutama polen. Menurut Neupane \& Thapa (2005) produksi sel anakan lebah pada suatu koloni A. mellifera dipengaruhi oleh waktu kapan dimulainya musim gugur dan ketersedian polen alami. Selain itu, polen tidak hanya memengaruhi tingkat produksi sel anakan lebah, tetapi juga menjadi faktor yang penting bagi lebah pekerja yang baru menetas untuk membentuk kelenjar hypopharyngeal (Hoover \& Ovinge, 2018; Khan et al., 2021; Pattamayutanon et. al., 2018). Lebih lanjut, studi oleh Fine et al., (2018) dan Maia-Silva et. al. (2015) menunjukkan bahwa ratu lebah yang diberi makan roti atau polen lebah segar dan roti atau polen lebah beku menghasilkan jumlah telur dan merubah struktur sel anakan lebah yang signifikan lebih banyak jika dibandingkan yang hanya diberi makan polen buatan. Selain itu, hasil studi yang dilakukan oleh Hassan (2011) menunjukkan bahwa kadar crude protein polen bunga sawit mencapai $31,11 \%$ dan termasuk pada kategori terbaik (excellent) (Saleh et. al., 2021; Bujang et. al., 2021). Kedua adalah faktor lokasi yang tidak cocok terutama pada hutan pinus dan kebun kaliandra yang termasuk pada kategori dataran tinggi yang tidak sesuai dengan habitat alami H. itama. Zaki \& Razak (2018), menyatakan bahwa habitat asli H. itama adalah di dataran 
rendah hutan tropis yang didominasi oleh famili Dipterocarpaceae.

Beberapa dugaan mengenai fenomena ini antara lain adalah jumlah pakan lebah berupa polen dan nektar di lokasi hutan pinus yang rendah dan tingkat kesesuaian lokasi yang mempengaruhi aktivitas H. itama. Menurut Wallace \& Lee (2010), pada jenis lebah tidak bersengat, salah satunya adalah jenis H. itama, sekitar 10$20 \%$ lebah pekerjanya memiliki tugas untuk mengumpulkan polen dan resin sedangkan sisanya bekerja mengumpulkan nektar yang berlangsung dari pagi sampai sore hari (Basari et. al., 2018; Jaapar et. al., 2018). Jika dihubungkan dengan studi tersebut, maka faktor rendahnya sumber pakan menjadi salah satu faktor yang memengaruhi jumlah kantung madu di lokasi hutan pinus yang didominasi jenis Dicranopteris linearis dan jenis Pinus merkusii. Di lokasi kebun kaliandra meskipun memiliki potensi nektar yang banyak (Gusneta \& Nukmal, 2014; Hernández-Conrique et al., 2007), namun tidak dapat dimanfaatkan oleh $\mathrm{H}$. itama untuk mengkonversinya menjadi madu yang dapat dilihat dari jumlah kantung madu yang terbentuk. Hasil yang sama juga terlihat pada koloni yang ditempatkan di kebun sawit. Menurut Syafrizal et al. (2012), jenis tanaman kelapa sawit tidak menghasilkan nektar dan hanya memproduksi polen sehingga penambahan kantung madunya tidak banyak.

Selain itu, faktor lingkungan terutama temperatur diperkirakan menjadi faktor utama karena lokasi kebun kaliandra berada di dataran tinggi yang memiliki temperatur berkisar antara $12-25^{\circ} \mathrm{C}$ (BMKG, 2020). Menurut Jaapar et al. (2018) temperatur lingkungan yang optimal bagi $\mathrm{H}$. itama adalah berkisar antara $29-32^{\circ} \mathrm{C}$ dan habitat di dataran rendah. Di lokasi lahan pekarangan memiliki penambahan kantung madu terbanyak pada setiap pengamatannya karena didukung oleh dua faktor, yaitu faktor kesesuaian lokasi yang berada di dataran rendah (Jaapar et al., 2018) dan faktor ketersediaan tanaman pakan (Adgaba et al., 2017; Agussalim et. al., 2017).

Jika pengamatan dilakukan terhadap parameter penambahan jumlah kantung untuk setiap pengamatannya, maka diperoleh informasi bahwa jumlah kantung polen tertinggi terdapat pada kebun sawit, sedangkan hutan pinus dan kebun kaliandra merupakan yang terendah. Selain faktor lingkungan yang berada pada dataran tinggi yang salah satunya berdampak pada temperatur yang relatif rendah, faktor penduga lainnya adalah ketidaksukaan lebah terhadap polen pinus yang termasuk pada kelas rendah karena hanya memiliki kandungan protein 7\% (Somerville, 2005).

Tingginya jumlah kantung polen yang berhasil terbentuk pada areal kebun sawit disebabkan dua faktor, yaitu faktor kesesuaian lokasi yang berada di dataran rendah (Atmowidi et al., 2018; Jaapar et al., 2018) dan ketersedian pakan berupa polen sawit yang melimpah serta termasuk pada kualitas yang baik (Hassan, 2011; Somerville, 2005). Fenomena unik lainnya jika dihubungkan dengan jumlah kantung madu yang berbanding terbalik, maka menurut Leonhardt et. al. (2007) Lebah Kelulut akan mengisi organ crop-nya atau organ seperti lambung yang berfungsi sebagai tempat menampung nektar dengan sedikit nektar yang berkosentrasi tinggi ketika memulai usaha pengumpulan polen dan resin. Berdasarkan pemanfaatannya, nektar digunakan sebagai sumber tenaga dalam pencarian nektar, polen, dan resin (fuel hypothesis) serta berfungsi sebagai perekat polen (glue hyphotesis) (Roulston et. al., 2000). Rendahnya jumlah kantung madu diduga selain disebabkan keterbatasan tanaman penghasil nektar di areal kebun sawit juga diakibatkan oleh kebutuhan terhadap aktivitas lebah kelulut dalam mengumpulkan polen yang membutuhkan energi dan juga penggunaan nektar sebagai bahan baku perekat polen pada bagian kaki lebah.

Hasil analisis vegetasi di hutan pinus, tanaman bawah yang mendominasi adalah 
jenis Dicranopteris linearis dan jenis Pinus merkusii untuk tingkat pohon. Kedua jenis vegetasi ini tidak menghasilkan nektar dan polen yang penting bagi lebah H. Itama, sehingga diduga berpengaruh terhadap koloni lebah. Hal ini sesuai dengan studi oleh Widhiono, Sudiana, \& Yani (2017) yang menyatakan hanya ditemukan sebelas ekor jenis lebah Tetragonula laeviceps pada pengamatan yang dilakukan di hutan pinus Gunung Slamet pada periode AprilAgustus. Selain itu menurut Ellis et. al. (2010), meskipun menghasilkan polen, polen P. merkusii tidak dapat dimanfaatkan oleh lebah madu. Lebih lanjut Ellis et al. (2010) menambahkan bahwa resin yang menjadi kesukaan lebah tidak bersengat berasal dari jenis pohon Aghatis borneensis (famili Araucariaceae), Shorea parvifolia (famili Dipterocarpaceae), dan Parashorea tomentella (famili Dipterocarpaceae). Jika dihubungkan dengan studi tersebut, maka dapat diduga bahwa $\mathrm{H}$. itama kurang menyukai resin P. merkusii.

Hasil analisis struktur vegetasi di lahan pekarangan menunjukkan bahwa jenis Mimosa sp. (INP = 28,03) dan Assystasia sp. $(\mathrm{INP}=23,60)$ merupakan jenis vegetasi tingkat semai yang dominan. Jenis Assystasia sp. merupakan kelompok tumbuhan bawah berdaun lebar yang memiliki kelopak bunga berukuran kecil $(<3 \mathrm{~mm})$, sehingga hanya dapat dimasuki oleh jenis lebah tidak bersengat seperti H. itama dan hal ini menyebabkan tidak terjadinya kompetisi dengan lebah bersengat seperti jenis A. cerana dan A. dorsata. Karet (Hevea brasiliensis) (INP $=17,59)$ dan kelapa (Cocos nucifera) $(\mathrm{INP}=18,09)$ merupakan jenis yang mendominasi pada tingkat pohon. Pada karet, nektar disekresikan secara ekstraflora melalui pangkal trifoliate daun muda yang melimpah pada musim gugur daun dan pembentukan daun baru (Koptur, 2005). Hasil analisis vegetasi di kebun kaliandra, meskipun kaliandra mendominasi pada tingkat pohon, tiang, dan pancang, ketidaksesuaian habitat yang berada di daerah dataran tinggi (Jaapar et al., 2018) menyebabkan salah satu faktor rendahnya jumlah kantung madu.

Pada lokasi kebun sawit, hasil analisis vegetasi menunjukkan bahwa jenis Paspalum conjugatum $(\mathrm{INP}=19,50)$ dan Assystasia sp. (INP $=15,50)$ merupakan jenis yang mendominasi pada tingkat semai di kebun sawit. Kelapa sawit mendominasi struktur vegetasi pada tingkat pohon. Sistem budi daya di perkebunan sawit yang meminimalisasi pertumbuhan dan perkembangan tumbuhan bawah semakin mengurangi dan menekan perkembangan tumbuhan bawah. Selain itu, tidak adanya penetrasi cahaya juga menjadi faktor pembatas bagi tumbuhan bawah untuk berbunga (Stanton et. al., 2010), sehingga populasi tumbuhan bawah yang berpotensi menghasilkan nektar menjadi sedikit.

Tipe habitat memiliki pengaruh terhadap perkembangan lebah. Sebuah studi yang dilakukan oleh Kaluza et. al. (2018) menunjukkan bahwa kelompok lebah sosial akan lebih cepat berkembang pada ekosistem yang memiliki keragaman tanaman berbunga, sehingga memiliki ketersedian sumber pakan yang akan selalu terjaga. Studi lain yang dilakukan oleh Buchori et. al. (2020) juga memperlihatkan bahwa keragaman lanskap memengaruhi pertumbuhan koloni dan kemampuan reproduksi lebah, dimana area pertanian yang bersifat musiman memiliki pertumbuhan koloni yang rendah dibanding ekosistem yang beragam. Hasil pengamatan menunjukkan adanya fenomena yang menarik. Pertama, perkembangan koloni di lokasi yang didominasi oleh kelapa sawit menunjukkan peningkatan sel anakan lebah dan kantung tepung sari lebih tinggi dibandingkan lokasi pekarangan yang lebih beragam. Namun, di lokasi lain yang didominasi oleh pinus, memperlihatkan nilai pertumbuhan sel anakan lebah, kantung madu, dan kantung tepung sari yang rendah.

Tepung sari kelapa sawit selain memiliki kualitas yang baik, kuantitasnya 
juga terjaga hampir sepanjang tahun karena tidak mengenal musim. Dengan demikian, keragaman tanaman pakan diperlukan untuk menjaga kontinuitas sumber pakan. Apabila di sekitar lokasi terdapat sumber pakan yang memiliki kualitas, kuantitas, dan memiliki konsistensi yang baik atau tidak mengenal musim, maka tidak diperlukan keragaman tanaman pakan. Menurut Seeley (2010), koloni lebah mengenal suatu sistem kolektivitas yang dinamakan demokrasi lebah. Salah satunya digunakan dalam menentukan lokasi sumber pakan melalui tarian lebah. Setelah keputusan mengenai lokasi sumber pakan tercapai (quorum), maka seluruh lebah pekerja akan mengeksploitasi lokasi tersebut. Hal ini akan mencegah pengumpulan nektar dan tepung sari secara acak dan tidak terstruktur oleh para lebah pekerja. Lebih lanjut, studi yang dilakukan oleh Pribadi \& Purnomo (2013) dan Pribadi \& Purnomo (2013) menunjukkan bahwa lebah A. cerana dan A. mellifera yang ditempatkan pada lokasi antara kebun sawit menunjukkan perkembangan yang baik dan tidak perlu menerapkan migratory system untuk memenuhi kebutuhan nektar dan tepung sari.

\section{Kesimpulan dan Saran}

\subsection{Kesimpulan}

Perkembangan volume sel anakan lebah H. itama tertinggi terdapat di kebun sawit pada bulan Oktober dan terendah terdapat di hutan pinus. Jumlah kantung madu terbanyak terdapat di lahan pekarangan dan terendah terdapat di hutan pinus. Perkembangan jumlah kantung polen, jumlah tertinggi terdapat di lokasi kebun sawit dan terendah di hutan pinus. Budi daya Lebah Kelulut jenis H. itama lebih cocok dilakukan pada dataran rendah dengan kondisi vegetasi yang cenderung heterogen dibandingkan pada dataran tinggi. Kesesuaian lokasi disesuaikan dengan tujuan yang ingin didapatkan oleh peternak, jika ingin memproduksi madu, pekarangan menjadi lokasi yang cocok untuk dipilih. Jika menginginkan produksi polen dan memperbanyak koloni, maka budi daya $\mathrm{H}$. itama dapat dilakukan di kebun sawit.

\subsection{Saran}

Hasil penelitian ini dapat memberikan informasi bagi masyarakat peternak lebah kelulut, agar sebaiknya memperhatikan aspek pemilihan lokasi untuk memperoleh hasil yang optimal dan meminimalisasi kegagalan. Hal ini disebabkan kebutuhan masing-masing jenis kelulut adalah berbeda. Untuk memaksimalkan produksi madu, sebaiknya tidak hanya memperhatikan aspek tanaman pakan yang melimpah, tetapi aspek abiotik lain, seperti temperatur udara dan ketinggian lokasi adalah menjadi sesuatu yang penting. Hasil penelitian ini menunjukkan bahwa budi daya $\mathrm{H}$. itama sebaiknya dilakukan pada lokasi dataran rendah yang memiliki kondisi vegetasi yang heterogen. Penelitian selanjutnya perlu dilakukan untuk mengetahui perkembangan $\mathrm{H}$. itama di dataran rendah yang memiliki kondisi vegetasi homogen dan didominasi tumbuhan penghasil nektar, seperti Acacia crassicarpa.

\section{Ucapan Terima Kasih}

Penulis mengucapkan terima kasih kepada Syasri Janneta dan Suhendar atas bantuannya di lapangan. Selain itu, kami juga berterima kasih kepada pihak Balai Taman Nasional Bukit Tiga Puluh yang dapat memfasilitasi kegiatan pengambilan data di Kelurahan Selensen. Terima kasih juga diucapkan kepada masyarakat desa di Kabupaten Tanah Datar dan Kabupaten Kampar atas partisipasinya dalam kegiatan penelitian. 


\section{Daftar Pustaka}

Adgaba, N., Al-Ghamdi, A., Tadesse, Y., Getachew, A., Awad, A.M., Ansari, M. J., \& Alqarni, A.S. (2017). Nectar secretion dynamics and honey production potentials of some major honey plants in Saudi Arabia. Saudi Journal of Biological Sciences, 24(1), 180-191. https://doi.org/10.1016/j.sjbs .2016 .05 .002

Agussalim, Agus, A., Umami, N., \& Budisatria, I.G.S. (2017). The effect of daily activities stingless bees of Trigona sp. on honey production. The $7^{\text {th }}$ International Seminar on Tropical Animal Production, 223-227.

Bankova, V., Bertelli, D., Borba, R., Conti, B.J., da Silva Cunha, I.B., Danert, C., \& Zampini, C. (2019). Standard methods for Apis mellifera propolis research. Journal of Apicultural Research, 58(2), 1-49. https://doi.org/10.1080/00218839.201 6.1222661

Basari, N., Ramli, S.N., Khairi, M.N., \& Aina, S. (2018). Food reward and distance influence the foraging pattern of stingless bee, Heterotrigona itama. Insects, 9(4). https://doi.org/10.3390/ insects 9040138

BMKG (Badan Meteorologi, Klimatologi, dan Geofisika). (2020). Prakiraan Cuaca: Kabupaten Tanah Datar.

Buchori, D., Rizali, A., Priawandiputra, W., Sartiami, D., \& Johannis, M. (2020). Population growth and insecticide residues of honey bees in tropical agricultural landscapes. Diversity, 12(1). https://doi.org/10.3390/d12010 001

Bujang, J.S., Zakaria, M.H., \& Ramaiya, S.D. (2021). Chemical constituents and phytochemical properties of floral maize pollen. PLoS ONE, $16(2$ February 2021), 1-15. https://doi.org/ 10.1371/journal.pone.0247327

De Menezes Pedro, S.R. (2014). The stingless bee fauna in Brazil
(Hymenoptera: Apidae). Sociobiology, 61(4), 348-354. https://doi.org/10.131 02/sociobiology.v61i4.348-354

Ellis, A., Ellis, J., O’Malley, M., \& Nalen, C. (2010). The Benefits of Pollen to Honey Bees. University of Florida Extension.

Engel, M. (2012). The honeybee of Indonesia (Hymenoptera: Apiae). Treubia, 39(December), 41-49.

Engel, M.S., Kahono, S., \& Peggie, D. (2019). A key to the genera and subgenera of stingless bees in Indonesia (Hymenoptera: Apidae). Treubia, 45(December), 65-84. https: //doi.org/10.14203/treubia.v45i0.3687

Erwan, \& Yanuartati, B.Y.E. (2012). Breeding of queen bee and farm business developing as business activity at the beekeepers group in West Lombok Regency. Mataram.

Fadhilah, R., \& Rizkika, K. (2015). Laba: Lebah Tanpa Sengat. Trubus.

Fine, J.D., Shpigler, H.Y., Ray, A.M., Beach, N.J., Sankey, L., Cash-ahmed, A., \& Robinson, G.E. (2018). Quantifying the effects of pollen nutrition on honey bee queen egg laying with a new laboratory system. PLoS ONE, 13(9), 1-16. https://doi. org/10.1371/journal.pone.0203444

Gusneta, D., \& Nukmal, N. (2014). Kandungan glukosa nektar dan madu sebagai sumber pakan lebah pada lokasi yang berbeda. Jurnal Pengembangan Teknologi Pertanian, 1(2), 299-307.

Harjanto, S., Mujianto, M., Arbainsyah, \& Ramlan, A. (2020). Budi daya Lebah Madu Kelulut Sebagai Alternatif Mata Pencaharian Masyarakat. Bogor: Goodhope Asia Holdings Ltd, Environmental Leadership \& Training Initiative (ELTI), Tropenbos Indonesia dan Swaraowa.

Hassan, H. (2011). Chemical composition and nutritional value of palm pollen grains. Global J Biotechnol Biochem, $6,1-7$. 
Hepburn, H.R., \& Radloff, S.E. (2011). Biogeography of the dwarf honeybees, Apis andreniformis and Apis florea. Apidologie, 42(3), 293-300. https://doi .org/10.1007/s13592-011-0024-x

Hoover, S.E., \& Ovinge, L.P. (2018). Pollen collection, honey production, and pollination services: Managing honey bees in an agricultural setting. Journal of Economic Entomology, 111(4), 1509-1516. https://doi.org/10.1093/ jee/toy 125

Jaapar, M.F., Jajuli, R., Mispan, M.R., \& Ghani, I.A. (2018). Foraging behavior of stingless bee Heterotrigona itama (Cockerell, 1918) (Hymenoptera: Apidae: Meliponini). In AIP Conference Proceedings 1940(4) (pp. 020037-1-020037-7). https://doi.org/10.1063/1.5027952

Kaluza, B.F., Wallace, H.M., Heard, T.A., Minden, V., Klein, A., \& Leonhardt, S. D. (2018). Social bees are fitter in more biodiverse environments. Scientific Reports, 8(1), 1-10. https://doi.org/ 10.1038/s41598-018-30126-0

Kek, S.P., Chin, N.L., Tan, S.W., Yusof, Y.A., \& Chua, L.S. (2017). Classification of honey from its bee origin via chemical profiles and mineral content. Food Analytical Methods, 10(1), 19-30. https://doi.org/ 10.1007/s12161-016-0544-0

Koptur, S. (2005). Nectar as fuel for plant protectors. Plant-Provided Food for Carnivorous Insects: A Protective Mutualism and Its Applications. https://doi.org/10.1017/CBO9780511 542220.004

Kuntadi, K., \& Andadari, L. (2013). Aktivitas akarisida beberapa minyak atsiri, insektisida nabati, dan cuka kayu terhadap Varroa destructor Anderson \& Trueman (Acari: Varroidae). Jurnal Penelitian Hutan Tanaman, 10(1), 3342. https://doi.org/10.20886/jpht.2013. 10.1.33-42

Kuntadi. (2016). Uji laboratorium dan lapang insektisida nabati bioprotektor.
Jurnal Penelitian Hutan Tanaman, 13(1), 61-72.

Lani, M.N., Zainudin, A.H., Razak, S.B.A., Mansor, A., \& Hassan, Z. (2017). Microbiological quality and $\mathrm{pH}$ changes of honey produced by stingless bees, Heterotrigona itama and Geniotrigona thoracica stored at ambient temperature. Malaysian Applied Biology, 46(3), 89-96.

Leonhardt, S.D., Dworschak, K., Eltz, T., \& Bluthgen, N. (2007). Foraging loads of stingless bees and utilisation of stored nectar for pollen harvesting. Apidologie, 38, 125-135. https://doi. org/10.1051/apido:2006059

Michener, C.D. (2007). The Bees of the World. 2nd editions. Baltimore, USA: The Johns Hopkins University Press.

Michener, C.D. (2013). The Meliponini. In Pothoney: a Legacy of Stingless Bees (Eds. P. Vit, Pedro, S.R.M., \& Roubik, D.W.) (pp. 1-17). New York: Springer Verlag.

Mohammad, S.M., Mahmud-Ab-Rashid, N.K., \& Zawawi, N. (2020). Botanical origin and nutritional values of bee bread of stingless bee (Heterotrigona itama) from Malaysia. Journal of Food Quality, 2020, 15-17. https://doi.org/ $10.1155 / 2020 / 2845757$

Neupane, K., \& Thapa, R. (2005). Pollen collection and brood production by honeybees (Apis mellifera L.) under Chitwan Condition of Nepal. J. Inst. Agric. Anim. Sci, 26. https://doi.org/ 10.3126/jiaas.v26i0.667

Ng, W.J., Sit, N.W., Ooi, P.A.C., Ee, K.Y., \& Lim, T.M. (2020). The antibacterial potential of honeydew honey produced by stingless bee (Heterotrigona itama) against antibiotic resistant bacteria. Antibiotics, 9(12), 1-16. https://doi. org/10.3390/antibiotics9120871

Nweze, J.A., Okafor, J.I., Nweze, E.I., \& Nweze, J.E. (2017). Evaluation of physicochemical and antioxidant properties of two stingless bee honeys: A comparison with Apis mellifera 
honey from Nsukka, Nigeria. BMC Research Notes, 10(1), 4-9. https://doi. org/10.1186/s13104-017-2884-2

Pribadi, A., \& Purnomo. (2013). Potency usage of plantation forest of acacia mangium and acacia crassicarpa as source of honeybee forage and its problems. In Procedings of International Wood Research Forestry 5th. Balikpapan: IWORS.

Pribadi \& Purnomo. (2013). Agroforestry sorghum (Sorghum sp.) pada HTI Acacia crassicarpa sebagai sebagai sumber pakan lebah Apis cerana di provinsi Riau untuk mendukung budi daya lebah madu. Prosiding Seminar Nasional Agroforestri, 2013, 36.

Pribadi, A., \& Wiratmoko, M.E. (2019). Karakteristik madu lebah hutan (Apis dorsata Fabr.) dari berbagai bioregion di Riau. Jurnal Penelitian Hasil Hutan, 37(3), 185-200.

Pribadi, A. (2020). The influence of vegetation compositions on Asian giant honey bee (Apis dorsata Fabr.) in Kampar Regency . IOP Conference Series: Earth and Environmental Science, 533, 012045. https://doi.org/ 10.1088/1755-1315/533/1/012045

Pribadi, A. (2020). Produktivitas panen propolis mentah lebah Trigona itama Cockerell (Hymenoptera: Apidae) menggunakan propolis trap dan manipulasi lingkungan di Riau. Majalah Ilmiah Biologi Biosfera: A Scientific Journal, 37(2), 60-68. https://doi.org/10.20884/1.mib.2020.3 7.2.1045

Pribadi, Yunianto, A.S., Hajjah, N., \& Sarah, F.A. (2020). Pemberdayaan dan usaha peningkatan ekonomi suku Talang Mamak di kawasan Taman Nasional Bukit Tiga Puluh melalui budi daya kelulut (Heterotrigona itama). In Unri Conference Series: Community Engagement, 2, 98-105. Pekanbaru: Universitas Riau. https://doi.org/10.31258/unricsce.2.98 $-105$
Riendriasari, S.D., \& Krisnawati. (2017). Produksi propolis mentah lebah madu Trigona spp. di Pulau Lombok. Jurnal Hutan Tropika, 1(1), 71-75. https://doi.org/10.32522/u-jht.v1i1. 797

Roulston, T.H., Cane, J.H., \& Buchmann, S.L. (2000). What governs protein content of pollen: pollinator preferences, pollen-pistil interactions, or phylogeny? Ecological Monographs, 70(4), 617-643. https:// doi.org/https://doi.org/10.1890/00129615(2000)070[0617:WGPCOP]2.0. $\mathrm{CO} ; 2$

Saleh, M., Kokoszyński, D., Abd-Allah Mousa, M., \& Abdel-Kareem Abuoghaba, A. (2021). Effect of date palm pollen supplementation on the egg production, ovarian follicles development, hematological variables and hormonal profile of laying hens. Animals, 11(1), 1-13. https://doi.org/ 10.3390/ani11010069

Seeley, T.D. (2010). Honeybee Democracy. Princeton: Princeton University Press. Retrieved from https://www.jstor.org/ stable/j.ctt7t4bk\%0A

Shamsudin, S., Selamat, J., Sanny, M., Bahari, S.A.R., Jambari, N.N., \& Khatib, A. (2019). A comparative characterization of physicochemical and antioxidants properties of processed Heterotrigona itama honey from different origins and classification by chemometrics analysis. Molecules, 24(21), 1-20. https://doi.org/10.3390/molecules242 13898

Stanton, K.M., Weeks, S.S., Dana, M.N., \& Mickelbart, M.V. (2010). Light exposure and shade effects on growth, flowering, and leaf morphology of Spiraea alba du roi and Spiraea tomentosa L. HortScience, 45(12), 1912-1916. https://doi.org/10.21273 /hortsci.45.12.1912

Syafrizal, S., Bratawinata, A., Sila, M., \& Marji, D. (2012). Diversity of kelulut 
bee (Trigona sp.) in Lempake Education Forest. Mulawarman Scientifiee, 11(1), 11-18.

Toreti, V.C., Sato, H.H., Pastore, G.M., \& Park, Y.K. (2013). Recent progress of propolis for its biological and chemical compositions and its botanical origin. Evidence-Based Complementary and Alternative Medicine, 2013. https://doi.org/10.1155/2013/697390

Trianto, M., \& Purwanto, H. (2020). Morphological characteristics and morphometrics of stingless bees (Hymenoptera: Meliponini) in Yogyakarta, Indonesia. Biodiversitas, 21(6), 2619-2628. https://doi.org/10. 13057/biodiv/d210633

Wallace, H.M., \& Lee, D.J. (2010). Resinforaging by colonies of Trigona sapiens and T. hockingsi (Hymenoptera: Apidae, Meliponini) and consequent seed dispersal of Corymbia torelliana (Myrtaceae). Apidologie, 41(4), 428-435. https://doi.org/10.1051/apido/2009074 Widhiono, I., Sudiana, E., \& Yani, E. (2017). Contribution of plantation forest on wild bees (Hymenoptera: Apoidea) pollinators conservation in Mount Slamet, Central Java, Indonesia. Biosaintifika: Journal of Biology \& Biology Education, 9(3), 437. https://doi.org/10.15294/biosain tifika.v9i3.10652
Wiratmoko, M.D.E., \& Pribadi, A. (2020). Physicochemical characteristics of west Sumatera's forest honey. IOP Conference Series: Earth and Environmental Science, 415(1). https://doi.org/10.1088/1755-1315/41 5/1/012015

Wong, P., Ling, H.S., Chung, K.C., Yau, T.M.S., \& Gindi, S.R.A. (2019). Chemical analysis on the honey of Heterotrigona itama and Tetrigona binghami from Sarawak, Malaysia. Sains Malaysiana, 48(8), 1635-1642. https://doi.org/10.17576/jsm-20194808-09

Zaki, M.N.N., \& Razak, A.S.B. (2018). Pollen profile by stingless bee (Heterotrigona itama) reared in rubber smallholding environment at Tepoh, Terengganu. Malaysian Journal of Microscopy, 14, 115-123. 